\title{
PERTANGGUNGJAWABAN PIDANA KORPORASI DILINGKUNGAN PT PLN PERSERO
}

\author{
Adi Lumakso \\ Magister Ilmu Hukum Universitas Suryakancana, Indonesia \\ E-mail: alumakso7@gmail.com
}

\begin{abstract}
Abstrak
Tujuan penelitian ini adalah untuk mengkaji tentang konsep pertanggungjawaban pidana korporasi pada lingkungan PT PLN Persero yang merupakan satu-satunya BUMN yang berkewajiban melaksanakan usaha penyediaan tenaga listrik. Metode penelitian yang digunakan adalah metode penelitian hukum normatif dengan menggunakan pendekatan peraturan perundang-undangan dan pendekatan konseptual. Berdasarkan hasil penelitian bahwa kedudukan PT. PLN (Persero) sebagai Badan Usaha Milik Negara (BUMN) berkewajiban memberikan pelayanan yang terbaik kepada konsumen dan pelanggan, karena listrik merupakan salah satu kebutuh primer pada saat ini untuk masyarakat. Salah satu kewajiban pelayanan yang diatur dalam undang-undang adalah penyediaan tenaga listrik secara terus menerus dengan mutu dan keandalan yang baik. Oleh karena itu, pelanggaran terhadap aturan ini, dapat dikenai pertanggungjawaban pidana.
\end{abstract}

Kata Kunci: Pertanggungjawaban; Pidana; Korporasi.

\begin{abstract}
The purpose of this study is to examine the concept of corporate criminal liability in the environment of PT PLN Persero, which is the only BUMN that is obliged to carry out the business of providing electricity. The research method used is a normative legal research method using a statutory approach and a conceptual approach. Based on the research results that the position of PT. PLN (Persero) as a State Owned Enterprise (BUMN) is obliged to provide the best service to consumers and customers, because electricity is one of the primary needs at this time for the community. One of the service obligations regulated in the law is the continuous supply of electricity with good quality and reliability. Therefore, violations of this rule, can be subject to criminal liability.
\end{abstract}

Keywords: Accountability; Criminal; Corporation.

\section{A. PENDAHULUAN}

Energi listrik merupakam bagian dari peradaban umat manusia yang utama dalam menjalankan aktifitas baik kebutuhan hidup manusia atau kebutuhan industri. Listrik sudah menjadi salah satu kebutuhan yang tak terpisahkan dengan manusia, karena berkaitan dengan basis perekonomian secara menyeluruh. Mulai dari kalangan bawah hingga kalangan.

Energi listrik juga merupakan kebutuhan nasional untuk hajat hidup orang banyak sehingga ketersediaanya harus dilindungi oleh pemerintah. Tetapi kini kondisinya dilematis PT. PLN (Persero) sebagai korporasi yang diberikan kepercayaan oleh pemerintah untuk mengelola sumber daya listrik demi menjamin ketersediaan pasokan kepada pelanggan tersebut kerap kali membuat kebijakan yang bertolak belakang dengan visi pengeloaan sumber daya alam sesuai dengan amanat Pasal 33 Undang-Undang Dasar 1945. ${ }^{1}$

Di tengah masyarakat yang "serba elektronik" ini, rasanya kehadiran dan manfaat energi listrik begitu tak terelakkan lagi. Semenit saja listrik padam, masyarakat (perkotaan) terlihat begitu gugup, bahkan panik. Tidak bisa dibayangkan jika suatu kota metropolitan terhenti

${ }^{1}$ Titiek Sri Wahyuni. (2012). Pertanggungjawaban Pidana Korporasi (Pt.Pln) Dalam Tindak Pidana Perlindungan Konsumen. Tesis: Program Studi Magister Ilmu Hukum Pascasarjana Universitas Hasanuddin Makassar, hlm. 4.

104 Adi Lumakso | Pertanggungjawaban Pidana Korporasi... 
pasokan listriknya selama satu minggu saja, maka akan tercipta kondisi rawan kejahatan, kematian sia-sia pasien rumah sakit, serta kekacauan pada sistem transportasi yang ada. ${ }^{2}$

PT. PLN (Persero) merupakan satu-satunya Badan Usaha Milik Negara (BUMN) yang berkewajiban melaksanakan usaha penyediaan tenaga listrik. Kedudukan PT. PLN (Persero) sebagai Badan Usaha Milik Negara (BUMN) berkewajiban memberikan pelayanan yang terbaik kepada konsumen dan pelanggan. Salah satu kewajiban pelayanan yang diatur dalam undangundang adalah penyediaan tenaga listrik secara terus menerus dengan mutu dan keandalan yang baik. Oleh karena itu, pelanggaran terhadap aturan ini, dapat dikenai pertanggungjawaban pidana

Tinggi rendahnya komsumsi listrik per kapita, menunjukkan derajat kesejahteraan masyarakat suatu bangsa. ${ }^{3}$ Kondisi ini direspon PLN dengan terus meningkatkan kinerjanya mulai tahap inisiasi dan perencanaan melalui penerbitan RUPTL (Rencanan Umum Pembangunan Tenaga Listrik) yang tiap tahun direvisi sesuai pertumbuhan beban dan makro ekonomi nasional, program pembangunan ketenagalistrikan melalui alokasi anggaran per tahun dengan rata-rata investasi sebesar Rp. $100 \mathrm{~T}$ melalui program RKAP (Rencana Kerja dan Anggaran Perusahaan) dimana alokasi pembangunan disesuaikan dengan pertumbuhan beban di tiap regional. Hasil kerja keras ini di tahun 2019 PLN telah berhasil melistriki 99,3 $\%$ dari total desa yang ada di Indonesia dan mentargetkam akan melistriki 100\% seluruh desa per tanggal 27 Oktober 2020 bertepatan dengan ulang tahun PLN ke 75 tahun. Suatu usia yang cukup matang dan mapan dalam tata kelola koropasi sesuai asas good corporate governance dan sebagai bukti PT. PLN (Persero) tetap exist dalam menjalankan tugas dan fungsinya di tengah pasang surut ekonomi, badai pergolakan sosial politik, kemajuan ilmu pengetahuan dan teknologi dan perubahan generasi. Namun prestasi ini masih sering dinodai dengan beberapa berita negatif tentang PLN seperti penahanan dan kurungan penjara bagi pejabat tingkat direksi, general manajer, manajer sampai tingkat fungsional karena kasus korupsi khususnya dalam hal pengadaan barang dan jasa. Sudah 4 (empat) Direktur Utama PLN secara berturutturut menyandang status tersangka, sebuah status yang sangat dihindari tapi harus dihadapi terkait dengan resiko jabatan dalam pengambilan keputusan. Kasus terakhir adalah black out di wilayah Jakarta dan Jawa Barat selama 10 Jam telah menimbulkan kegamangan insan PLN dalam menjalankan tugas pokok dan fungsinya dalam penyediaan energy listrik yang handal, dengan diperiksanya puluhan pejabat tingkat rendah sampai direktur utama oleh Bareskrim Polri, yang akhirnya dapat diselesaikan melalui jaminan pihak penguasa. Secara tekonologi kondisi ini dapat dijelaskan secara mudah namun sulit dipahami secara sosial politik karena kebijakan yang memicu kejadian ini merupakan bagian kebijakan nasional untuk melakukan efisiensi dan penghematan devisa dalam import energi primer.

Urgensi tindak penyelewangan yang dilakukan dilingkungan PLN pada saat ini sangatlah lemah dan banyak sekali kegagalan-kegagalan di Indonesia yang menganut sistem hukum Civil Law. Suatu kasus perlu tindakan yang cepat dan segera tetapai pada saat ini dalam penanganan suatu kasus sangatnya lama dan terkesan lambat, dan banyak sekali kasus yang kandas karena pengadilan dikalahkan oleh korporasi. Dengan di menangkan suatu kasus penyelewangan, korupsi dan sebagainya nantinya sangat bermanfaat bagi negara apabila korporosi memihak Negara, dibandingkan dengan putusan Hakim yang pada saat ini sangatlah kecil denda dan hukuman yang diberikan oleh pelaku tindak pidana ini.

Kendati begitu kompleksnya masalah yang dihadapi, pemerintah belum mempunyai rumus jitu untuk mengatasinya.Undang-Undang Ketenagalistrikan yang diharapkan bisa menjadi

\footnotetext{
${ }^{2}$ Ariono Abdulkadir dkk. (2004), Masalah Ketenagalistrikan di Indonesia (kumpulan artikel), Jakarta: YLKI \& Koalisi Masyarakat Sipil untuk Perbaikan Pelayanan Listrik hlm. i.

${ }^{3}$ Tim YLKI. (2010). Bersikap Kritis Bertindak Cermat (Panduan Konsumen Menghadapi PenertibanPemakaian Tenaga Listrik), Jakarta: Yayasan Lembaga Konsumen Indonesia, hlm. 3.
} 
jalan keluar yang komprehensif, terbukti malah diragukan banyak pihak dengan kebebasan tidak terbatas investor kelistrikan yang hanya mementingkan kepentingan bisnis sesaat dengan abai terhadap faktor fundamentalis ekonomi dan sosial.

Pertanggungjawaban pidana pada dasarnya dapat dikenakan kepada setiap subjek hukum yang melakukan pelanggaran terhadap peraturan perundang-undangan yang berlaku. Subjek hukum yang dapat dimintai pertanggungjawaban (pidana) adalah orang- perseorangan dan badan hukum (korporasi). Dalam hal ini, oleh PT. PLN (Persero) sebagai sebuah badan hukum dapat pula dikenai pertanggungjawaban pidana apabila melanggar peraturan perundangundanga, maka munculah suatu permasalahan bagaimana pertanggungjawaban pidana korporasi di PT. PLN Persero, bagi pelaku penyelewengan di lingkungan PT. PLN.

\section{B. METODE PENELITIAN}

Metode penelitian ini bersifat yuridis normatif sebagai pendekatan utama, mengingat pembahasan didasarkan pada peraturan perundang-undangan dan prinsip hukum yang berlaku dalam masalah Pertanggungjawaban Pidana Korporasi Bagi Pelaku Penyelewangan Dilingkungan PT PLN Persero, ditinjau dari Undang-Undang Nomor 2 Tahun 2017 Tentang Jasa Kontruksi dan Undang-Undang Nomor 31 Tahun 1999 tentang Pemberantasan Tindak Pidana Korupsi. Pendekatan yuridis dimasudkan untuk melakukan pengkajian terhadap bidang hukum, khususnya hukum pidana. Pendekatan yuridis komparatif yaitu dengan menginventarisasi dan mengkaji atau menganalisis data sekunder yang berupa bahan-bahan hukum primer dan bahan hukum sekunder dengan memahami hukum sebagai perangkat peraturan atau norma-norma positif di dalam sistem perundang-undangan yang mengatur mengenai kehidupan manusia. Selain itu juga digunakan pendekatan komparatif yang digunakan sebagai pertimbangan dalam menentukan arah kebijakan formulasi di masa yang akan datang.

\section{PEMBAHASAN}

\section{Pertanggungjawaban Pidana Korporasi}

Orang yang melakukan perbuatan pidana dapat dipidana apabila di dalamnya ada unsur kesalahan. Sehingga untuk adanya kesalahan yang mengakibatkan dipidananya terdakwa maka terdakwa haruslah :

a. Melakukan perbuatan pidana;

b. Mampu bertanggung jawab;

c. Dengan sengaja atau kealpaan;

d. Tidak adanya alasan pemaaf. ${ }^{4}$

Korporasi sebagai subjek tindak pidana, menimbulkan suatu permasalahan yang menyangkut pertanggungjawaban dalam hukum pidana, yaitu apakah badan hukum dapat mempunyai kesalahan, baik berupa kesengajaan atau kealpaan. Sebab, bagaimanapun kita masih menganut asas " tiada pidana tanpa kesalahan " ( dalam Undang- Undang Nomor 4 Tahun 2004, yaitu dalam Pasal 6 ayat 2 Undang-Undang Kekuasaan Kehakiman ). Sehubungan dengan hal tersebut, dapatkah korporasi mempunyai alasan yang dapat menghapuskan pemidanaan, seperti halnya subjek hukum manusia.

Korporasi sebagai subjek hukum bersifat tidak dapat diindera (invisible) dan tidak berwujud (intangible) yang bersifat terpisah dari para pemiliknya. Dalam menjalankan perusahaan

${ }^{4}$ MR. Roeslan Saleh. (1980). Perbuatan Pidana dan Pertanggungjawaban Pidana. Jakarta: Aksara Baru, hlm. 78-79.

106 Adi Lumakso | Pertanggungjawaban Pidana Korporasi... 
korporasi dapat membuat perjanjian (contracts), membeli atau menjual barang, menuntut atau dituntut dimuka pengadilan, membuat perjanjian sewa-menyewa, dan membayar pajak. Sekalipun tidak dapat dipenjara, korporasi tunduk pada hukum pidana. Hutanghutang korporasi menjadi hutang perusahaan dan bukan hutang pribadi dari para pemiliknya (pemegang saham). ${ }^{5}$

Karena dalam praktik sangat tidak mudah menentukan ada atau tidak adanya kesalahan pada korporasi, ternyata dalam perkembangannya khususnya yang menyangkut pertanggungjawaban pidana korporasi dikenal adanya " pandangan baru ", atau katakanlah pandangan yang agak berlainan, bahwa khusus untuk pertanggungjawaban dari badan hukum, asas kesalahan tidak mutlak berlaku. Sehingga pertanggungjawaban pidana yang mengacu pada doktrin strict liability dan vicarious liability yang pada prinsipnya merupakan penyimpangan dari asas kesalahan, hendaknya dapat menjadi bahan pertimbangan dalam penerapan tanggungjawab korporasi dalam hukum pidana. ${ }^{6}$ Walaupun demikian, di Inggris sama sekali tidak meninggalkan asas mensrea dalam pertanggungjawaban pidana korporasi, sebab di Inggris terdapat asas identifikasi. Berdasarkan asas ini korporasi pada dasarnya dapat dipertanggungjawabkan sama dengan orang pribadi.

Selanjutnya, tentang pertanggungjawaban korporasi dalam hukum pidana menurut Glanville Williams, dikatakan : "The liability of corporation, like strict liability exemplifies utilitarians theory in the criminal law. It is based not on the theory of justice but upon the need for deterrence. ${ }^{7}$ Yang artinya kurang lebih adalah, "Tanggung jawab korporasi, seperti kewajiban ketat mencontohkan teori utilitarian dalam hukum pidana. Hal ini didasarkan bukan pada teori keadilan, tetapi pada kebutuhan untuk pencegahan".

Black's Law Dictionary, menyatakan: "A corporate shareholfer's power to buy or sell the shares, though the shareholder is not registered on the corporation's books as the owner" Kekuasan pemegang saham korporat untuk membeli atau menjual saham, walaupun pemegang saham tidak terdaftar dalam pembukuan korporasi sebagai pemilik.

Selanjutnya dalam pendapat tersebut, Tim Ahli Penyusunan KUHP Baru dalam laporannya tahun 1985, menyatakan motivasi untuk pertanggungjawaban korporasi adalah :

"Dengan memperhatikan perkembangan koperasi itu, yaitu bahwa ternyata untuk beberapa delik tertentu ditetapkannya pengurus saja sebagai yang dapat dipidana rupanya tidak cukup. Dalam delik ekonomi bukan mustahil denda yang dijatuhkan sebagai hukuman kepada pengurus dibandingkan dengan keuntungan yang telah diterima oleh korporasi dengan melakukan perbuatan itu, atau kerugian yang ditimbulkan masyarakat, atau diderita oleh saingannya, keuntungan dan/atau kerugian itu adalah lebih besar daripada denda yang dijatuhkan sebagai pidana. Dipidananya pengurus tidak memberikan jaminan yang cukup bahwa korporasi tidak akan sekali lagi melakukan perbuatan yang dilarang oleh undang-undang itu. ${ }^{8}$

Pemidanaan terhadap korporasi, sekalipun sering dikaitkan dengan masalah finansial, namun sebenarnya mengandung tujuan yang lebih jauh. Dalam hal ini Friedmann berpendapat :

"The main effect and unsefulness of a criminal conviction imposed upon a corporation cannot be seen either in any personal injury or in most cases, in the financial detriment but in the public opprobrium and stigma that attaches to a criminal conviction". ${ }^{9}$

${ }^{5}$ Tri Budiyono. (2011). Hukum Perusahaan. Salatiga: Griya Media, hlm. 1-2.

${ }^{6}$ Muladi dan Dwidja Priyatno. (2010), Pertanggungjawaban Pidana Korporasi. Jakarta: Kencana, hlm. 17-18. ${ }^{7}$ Ibid. hlm. 18.

${ }^{8}$ Ibid. hlm. 18-19.

${ }^{9}$ Ibid. hlm. p. 20. 
Clinard dan Yeager mengemukakan kriteria kapan seharusnya sanksi pidana diarahkan pada korporasi. Apabila kriteria tersebut tidak ada, maka lebih baik sanksi perdatalah yang digunakan. Kriterianya adalah sebagai berikut :

a. The degree of loss to the public; Tingkat kerugian kepada masyarakat)

b. The level of complicity by high corporate managers; (Tingkat keterlibatan oleh manajer perusahaan tinggi)

c. The duration of the violation; (Durasi pelanggaran)

d. The frequency of the violation by the corporation; (Frekuensi pelanggaran oleh korporasi)

e. Evidence of intent to violate; ( Bukti niat untuk melanggar)

f. Evidenceofextortion, asinbriberycases;(Buktipemerasan, sepertidalamkasuspenyuapan)

g. The degree of notoriety enggendered by the media; (Tingkat ketenaran yang ditimbulkan oleh media)

h. Precedent in law; (Teladan dalam hukum)

i. The history of serious violations by the corporation; ( Sejarah pelanggaran serius oleh perusahaan)

j. Deterrence potential; (Pencegahan potensial)

$\mathrm{k}$. The degree of corporation evienced by the corporation. (Tingkat korporasi yang dibuktikan oleh korporasi). ${ }^{10}$

Adapun model pertanggungjawaban pidana dalam korporasi meliputi :

a. Pengurus korporasi sebagai pembuat dan penguruslah yang bertanggungjawab;

Dalam hal pengurus korporasi sebagai pembuat dan penguruslah yang bertanggungjawab, kepada pengurus korporasi dibebankan kewajiban tertentu. Kewajiban yang dibebankan itu sebenarnya adalah kewajiban dari korporasi. Pengurus yang tidak memenuhi kewajiban itu diancam dengan pidana. Sehingga dalam sistem ini terdapat alasan yang menghapuskan pidana. Sedangkan, dasar pemikirannya adalah korporasi itu sendiri tidak dapat dipertanggungjawabkan terhadap suatu pelanggaran, melainkan selalu penguruslah yang melakukan delik itu. Dan, karenanya penguruslah yang diancam pidana dan dipidana.

b. Korporasi sebagai pembuat dan pengurus yang bertanggungjawab;

Dalam hal korporasi sebagai pembuat dan pengurus bertanggungjawab, maka ditegaskan bahwa korporasi mungkin sebagai pembuat. Pengurus yang ditunjuk sebagai yang bertanggungjawab. Yang dipandang dilakukan oleh korporasi adalah apa yang dilakukan olehalatperlengkapankorporasimenurutwewenangberdasarkananggarandasarnya.Tindak pidana yang dilakukan oleh korporasi adalah tindak pidana yang dilakukan orang tertentu sebagai pengurus dari badan hukum tersebut. Sifat dari perbuatan yang menjadikan tindak pidana itu adalah onpersoonlijk. Orang yang memimpin korporasi yang bertanggungjawab pidana, terlepas dari apakah ia tahu atau tidak tentang dilakukannya perbuatan itu.

c. Korporasi sebagai pembuat dan juga sebagai yang bertanggungjawab.

Korporasi sebagai pembuat dan juga sebagai yang bertanggungjawab, motivasinya adalah dengan memperhatikan perkembangan korporasi itu sendiri, yaitu bahwa ternyata untuk beberapa delik tertentu, ditetapkannya pengurus saja sebagai yang dapat dipidana ternyata tidak cukup. Dalam delik ekonomi bukan mustahil denda yang dijatuhkan sebagai hukuman kepada pengurus dibandingkan dengan keuntungan yang telah diterima oleh korporasi dengan melakukan perbuatan itu, atau kerugian yang ditimbulkan dalam masyarakat, atau yang diderita oleh saingannya, keuntungan dan/atau kerugian itu adalah lebih besar daripada denda yang dijatuhkan sebagai pidana. Dipidananya pengurus tidak memberikan 
jaminan yang cukup bahwa korporasi tidak sekali lagi melakukan perbuatan yang telah dilarang oleh undang-undang itu.

Ternyata dipidananya pengurus saja tidak cukup untuk mengadakan represi terhadap delik oleh atau dengan suatu korporasi. Karenanya diperlukan pula untuk dimungkinkan memidananya korporasi (Pasal 15 Undang-Undang Nomor 7 Drt 1955 tentang Pengusutan, Penuntutan, dan Peradilan Tindak Pidana Ekonomi).

Sehubungan dengan hal tersebut Oemar Seno Adji, Guru Besar Hukum Pidana Universitas Indonesia dan mantan Ketua Mahkama Agung RI, menyatakan “ ... kemungkinan adanya pemidanaan terhadap persekutuan, ia didasarkan tidak saja atas pertimbangan utilitis, melainkan atas dasar-dasar yang teoritis dapat dibenarkan."

Berdasarkan beberapa alasan tersebut di atas, maka korporasi tersebut dapat dipertanggungjawabkan secara pidana. Dalam hal ini dihubungkan dengan peraturan perundang-undangan yang menganut bahwa korporasi dapat dipertanggungjawabkan secara langsung. Contoh ketentuan yang menempatkan korporasi sebagai subjek hukum pidana dan dapat dipertanggungjawabkan, yaitu:

a. Undang-Undang Nomor 7 Drt Tahun 1955 tentang Tindak Pidana ekonomi (Pasal 15);

b. Undang-Undang Nomor 6 Tahun 1984, tentang POS (Pasal 19 ayat 3);

c. Undang-Undang Nomor 5 Tahun 1997 tentang Psikotropika (Pasal 5 ayat 3);

d. Undang-Undang Nomor 31 Tahun 1999jo. Undang-Undang Nomor 20 Tahun 2001 tentang Pemberantasan Tindak Pidana Korupsi (Pasal 20);

e. Undang-Undang Nomor 15 Tahun 2003 tentang Tindak Pidana Pencucian Uang (Pasal 4 ayat 1$)$.

\section{Permasalahan Ketenagaanlistrik di Indonesia}

Bagi masyarakat modern, listrik sudah menjadi salah satu kebutuhan pokok yang tak terelakkan lagi. Terputusnya aliran listrik dapat mengganggu roda perekonomian, lebih membebani kehidupan keseharian, dan bahkan menimbulkan ketidaknyamanan. Lebih jauh, di samping listrik tidak boleh padam, masyarakat menuntut adanya kualitas listrik yang harus prima pula, misalnya tegangannya cukup dan stabil, frekuensinya stabil, dan bahkan tidak boleh berkedip.

Di Indonesia, yang rasio eletrifikasinya belum cukup tinggi ( hanya sekitar $60 \%$ ), di samping adanya tuntutan masyarakat akan kualitas listrik yang prima tersebut ( bagi masyarakat yang sudah berlangganan listrik ), peningkatan keterjangkauan listrik untuk masyarakat yang belum memiliki aliran listrik harus juga menjadi fokus perhatian pemerintah ( pusat dan daerah ) di dalam perumusan kebijakan sektor ketenagalistrikan. Sampai dengan saat ini, kita masih dihadapkan dengan berbagai masalah ketenagalistrikan yang belum dapat terselesaikan. ${ }^{11}$

Berbagai masalah ketenagalistrikan yang dihadapi bangsa kita saat ini meliputi :

a. Kebijakan di Sektor Ketenagalistrikan di Indonesia

Setiap ada rencana kenaikan tarif komoditas publik, seperti listrik, selalu ada polemik di masyarakat tentang pantas tidaknya sebuah kenaikan tarif. Secara teoritis, dalam pricing policy maing process komoditas publik, ada tiga variabel yang mesti diuji pantas tidaknya sebuah kenaikan tarif komoditas publik.

Pertama, rasioning dilakukan kenaikan, ada dua perspektif, yaitu perspektif operator / penyedia layanan, pada umumnya menggunakan alasan kenaikan biaya produksi. Kedua, dari perspektif konsumen, hal ini menyangkut ability to pay dan willingness to pay konsumeni.

${ }^{11}$ Ariono Abdulkadir dkk, Op. Cit., hlm. 3. 
Kedua, proses pengambilan keputusan kenaikan tarif komoditas publik, apakah sudah melalui mekanisme konsultasi publik di parlemen. Apakah operator dan konsumen sudah dimintai pertimbangan secara memadai sebelum keputusan tersebut dijatuhkan.

Ketiga, level efisiensi dari operator / penyedia layanan yang bersangkutan. Sekurangkurangnya ada dua parameter. Yaitu : ( 1 ) staffing ratio, perbandingan jumlah karyawan dengan pelanggan yang dilayani, sudah ideal atau belum; (2) tingkat kebocoran/ kehilangan/ susut baik teknis maupun non-teknis.

b. Perumusan tarif dasar listrik ( TDL )

Tarif dasar listrik ( TDL ) sangat dipengaruhi oleh biaya pembangkitan, yang meliputi biaya modal, biaya operasional dan maintenance, dan biaya bahan bakar.Sehingga strategi utama penentuan TDL ialah penekanan biaya pembangkitan, pemilihan jenis-jenis energi primer yang paling menguntungkan ( batubara, migas, hydropower, panas bumi ), kemudian melakukan energy mix untuk mendapatkan sistem yang optimum, andal dan ekonomis. Karena itu, sistem pembangkitan memerlukan investasi semua pihak termaksud investasi swasta dan memerlukan modal pinjaman.

Berlakunya TDL perlu dipertahankan untuk waktu yang cukup lama, sehingga dapat menghindari dampak psikologis, sosial dan politik setiap kali dilakukan penyesuaian. TDL harus diusahakan dekat dengan harga pasar yang realistik dan terkendali. Setiap kenaikan TDL harus dilakukan secara halus, step by step secara berkala untuk menghindari reaksi negatif dari konsumen.

Ada beberapa sebab yang dapat mempengaruhi pelaksanaan TDL dan besarnya tarif tersebut dimasa depan, antara lain ; pertama, ketersediaan energi primer batubara dan sistem pasokan. Kedua, olehkarena besarnyapengaruh biaya pembangkitan dalam TDLyangberlaku, sudah waktunya dibuat master-plan pengembangan energi primer di Indonesia sebagai wahana untuk mencapai energy security. Ketiga, pada prinsipnya subsidi harus dihapuskan terkecuali untuk daerah-daerah tertentu: NTT, Maluku dan Papua. Pelaksanaan subsidi akan menyebabkan terjadinya welfare loss untuk masyarakat yang lebih luas. Keempat, sesuai konsep pembangunan sektor energi yang berkesinambungan, terhadap biaya-biaya yang menyangkut lingkungann hidup, pencemaran lingkungan dan pengurasan sumber daya alam, perlu dimasukkan dalam TDL.

Dengan kenaikan TDL, penyelenggara ( PT. PLN ) harus memberikan jaminan kepada masyarakat terhadap peningkatan pelayanan, kualitas dan keandalan ( tanpa pemadaman ), keamanan pasokan dan peningkatan pelayanan pelanggan.

c. Listrik "Byar-Pet" dan undang-undang ketenagalistrikan

Diperkirakan lebih dari seratus kabupaten dan kotamadya di Indonesia mengalami listrik byar-pet sehingga harus mengalami pemadaman bergilir setiap harinya. ${ }^{12}$ Konsumen listrik jelas dirugikan oleh situasi ini. Pemadaman bergilir menyebabkan kerugian ekonomi dan sosial yang cukup besar bagi masyarakat.

MasalahyanglebihmendasaradalahkinerjakeuanganPLNyangburuksehinggamembatasi kemampuan PLN untuk melakukan investasi. Buruknya keuangan PLN ini disebabkan oleh biaya operasional perusahaanyang sangattinggi. Bagian pengeluaran terbesaryaitu pembelian bahan bakar, biaya perawatan dan kontrak jual beli listrik antara PLN dengan listrik swasta. d. Mutu dan keandalan penyediaan tenaga listrik

Sebagai konsumen listrik, kita acapkali mengalami pemadaman listrik secara tiba-tiba, dan seringnya tanpa pemberitahuan terlebih dahulu dari pihak PLN. Tak jarang, konsumen pun tidak pernah tahu sebab-musabab terjadinya pemadaman. Kalaupun ada pemberitahuan biasanya disampaikan dengan cara yang kurang meluas. Selain pemadaman, gangguan yang

\footnotetext{
${ }^{12}$ Ibid., hlm. 15 .
}

110 Adi Lumakso | Pertanggungjawaban Pidana Korporasi... 
sering dialami konsumen listrik adalah tidak stabilnya tegangan ( voltase ) aliran listrik. Contoh sederhana, jika tiba-tiba daya pancar sinar lampu di rumah kita meredup itu berarti tegangan listrik PLN sedang turun ( drop ). Yang lebih mengkhawatirkan, jika tegangan listrik tiba- tiba naik, dampaknya akan mempercepat / memperpendek usia alat elektronik yang bersangkutan.

Namun di lain pihak, PLNjuga mempunyai dalil bahwa bagaimanakamibisa memperbaiki kualitas pasokan tenaga listrik, jika dana untuk investasi yang tersedia sangat minim ? PLN mengaku bahwa TDL belum merupakan TDL yang ideal.

Bicara kualitas pasokan tenaga listrik ( dan lainnya ), tidak serta merta disebabkan oleh belum idealnya TDL. Namun juga dipengaruhi oleh berbagai management error yang dilakukan oleh managemen PLN.

Mutudankeandalanpenyediaantenagalistrikselainbergantungpadakapasitaspembangkit dan sistem jaringan, juga sangat tergantung pada sumberdaya manusia di lapangan yang akan memberikan pelayanan pada cepat atau lambatnya menangani gangguan.

e. Mutu dan Pelayanan PT. PLN PERSERO

1) Meningkatkan pelayanan komunikasi dengan cara menerima komplain bermanfaat dari konsumen

Komplain bukan sesuatu yang buruk, namun merupakan "ruh" yang membangun diri ke arah kedewasaan. Setiap kali ada komplain, bagi yang dewasa tentu akan memperbaiki dirinya. Semakin banyak komplain maka semakin kuatinstropeksi untukmemperbaiki diri.

Kritik yang berbentuk masukan adalah hadiah yang diberikan pelanggan kepada perusahaan. Membuka akses kepada pelanggan untuk menyampaikan kritik kepada perusahaan publik ketika melakukan pelayanan, bukan dosa, hingga tidak perlu ditakuti, malah semestinya terus digalakkan dan dirangsang.

Membuat anggapan perusahaanlah yang dibutuhkan dan bukan perusahaan yang membutuhkan pelanggan adalah tindakan keliru. Sebab sesungguhnya untuk menjaga kesetiaan pelanggan, paradigma salah itu perlu ditinggalkan. Perusahaan publik harus merasa bahwa dialah yang membutuhkan pelanggan, sehingga akan muncul sikap rendah hati dan siap melayani. Budaya rendah hati minimal dapat dimulai dari jalinan komunikasi, karena komunikasi juga membutuhkan rasa kerendahan hati dari petugas perusahaan.

Komitmen perusahaan untuk memuaskan pelanggan, pada umumnya hanya dipahami dalamjajaranelitemanajemenperusahaan.Komitmentersebutbelumterintelnalisasisecara merata sampai kepetugas lapangan. Level karyawan yang justru intensitas berinteraksi dengan pelanggan cukup tinggi.

Hal tersebut diperparah dengan buruknya komunikasi antara petugas lapangan dengan pelanggan. Buruknya pelayanan komunikasi mempunyai implikasi serius bagi kelangsungan usaha. Secara internal, akan menyulitkan pelaku usaha dalam upaya untuk memahami kemauan dan harapan pelanggan. Sedangkan dari sisi eksternal, buruknya komunikasi membuat situasi tidak kondusif bagi pelanggan untuk secara pro-aktif memberikan kritik, saran, keluhan kepada pelaku usaha.

2) Beban PT. PLN yang semakin berat

Meningkatnyaperalatankebutuhanmasyarakatseiringdenganpertumbuhanekonomi, mengakibatkan PLN kelimpungan menyediakan energi listrik. Termaksud persoalan pertumbuhan sektor industri, infrastruktur, hingga alat-alat elektronik masyarakat.

Faktor lain yang mengakibatkan PLN tidak mampu menyediakan energi listrik bahwa ternyata hingga kini mesin- mesin pembangkit energi listrik yang beroperasi tergolong 
sudah tidak layak pakai. Bahkan salah satu mesin PLN tahun 1868 masih digunakan memproduksi energi listrik melayani kebutuhan konsumen.

Dampak nyata dari ketidakmampuan PLN memasok energi listrik, dapat dilihat dari aksi pemadama bergilir. Ironisnya, ketika pasokan energi listrik sedang genting saat itu pula kota Makassar seolah disulap menjadi kota gemerlap yang menyedot energi listrik besar-besaran. Kalau hanya untuk menciptakan kota Makassar sebagai kota gemerlap tanpa ada upaya untuk mencari investor kelistrikan maka tidak ada gunanya jika suatu saat nanti kota ini menjadi gelap gulita karena beban puncak yang cukup tinggi.

3) Pemadaman bergilir potret kegagalan PLN

Investor mana yang tertarik dengan kondisi infrastruktur berupa ketersediaan tenaga listrik yang amburadur begini? apabila pemerintah serius membenahi infrastruktur, salah satunya penyediaan tenaga listrik secara terus menerus dengan mutu dan keandalan yang baik, tanpa pencanangan tahun investasi pun investor akan datang dengan sendirinya.

Akibat buruknya penyediaan tenaga listrik, telah menimbulkan kesengsaraan banyak pihak. Produksi industri kecil dan menengah turun $40 \%$ akibat terjadinya pemadaman bergilir. Asosiasi pengusaha hotel indonesia juga mengeluh karena sering mendapat komplain dari tamu. Belum lagi persewaan komputer tidak dapat beroperasi, sehingga banyak mahasiswa tidak dapat mengerjakan tugas-tugas perkuliahan.

Padahal apabila dilihat dari angka rata-rata tingkat komsumsi tenaga listrik penduduk Indonesia dibandingkan dengan sesama negara di kawasan Asia Tenggara masih sangat rendah. Akan tetapi, dari komsumsi yang sangat rendah tersebut dari fakta di atas dalam kenyataannya kualitasnya juga belum bisa diandalkan.

Haruskah sebuah pemadaman listrik terjadi ? selama ini ada mitos, apabila terjadi pemadaman selalu faktor alam dijadikan kambing hitam. Dan mitos ini sengaja dibangun olehpenyediatenagalistrik,pertamauntukmengalihkantanggungjawabdarifaktoroperator ( manusia ) ke faktor alam. Kedua, secara perlahan penyedia tenaga listrik telah berhasil membangun kesadaran di kalangan konsumen listrik untuk bisa menerima pemadaman listrik sebagai suatu kewajaran, bukan sebagai pelanggaran hak-hak konsumen.

PLN sendirisebenarnyasudahmembuktikan, bahwapemadamanlistrikbisadihindari.. sebagai contoh, keandalan pasokan listrik kompleks istana negara di jakarta. Di wilayah dengan daya listrik rata-rata 719, 4 VA ini hampir tidak pernah terjadi pemadaman. Kenapa bisa terjadi ? karena PLN menerapkan sistem back-up berlapis.

Belajar dari cara PLN menangani pasokan listrik kompleks istananegara, ada beberapa pesan yang dapat ditangkap, yaitu: (1 ) pemadaman listrik adalah suatu yang bisa dihindari; ( 2 ) apabila terjadi pemadaman listrik adalah menjadi tanggung jawab penyedia tenaga listrik ( PLN ); ( 3 ) kasus pasokan listrik istana negara adalah bukti yang sangat kongkrit bahwa PLN selama ini melakukan disparitas. PLN melakukan pelayanan yang berbeda terhadap sesama konsumen.

4) Tingginya losses (susut) PLN / Pendapatan yang hilang

Losses(susut)dalamindustriketenagalistrikandikategorikanmenjadidua, yaituteknis dan non-teknis. Susut teknis dapat terjadi dalam tahap pembangkitan, jaringan maupun distribusi. Banyak faktor yang menyebabkan susut teknis, antara lain umur kabel yang sudah tua, sambungan yang tidak sempurna dll.

Susut non-teknis, di lapangan dijumpai dalam bentuk ilegal connection atas pencurian listrik, baik dilakukan oleh pelanggan industri, rumah tangga, maupun penyambungan illegal untuk keperluan penerangan jalan umum.

112 Adi Lumakso | Pertanggungjawaban Pidana Korporasi... 
Dalam konteks kenaikan tarif listrik, index efisiensi berupa tinggi rendahnya angka susut amat penting. Sebab, secara finansial angka losses identik dengan biaya/pendapatan yang hilang. PT. PLN (Persero) sebagai perusahaan penyedia ketenagalistrikan setiap tahun mengalami losses (kehilangan pendapatan) dalam jumlah trilliunan rupiah.

Setiap persen losses setara dengan kehilangan pendapatan sebesar Rp. 800 miliar. Dengan berpatokan pada angka losses ideal sebesar 10 persen, maka tingkat losses PLN sebesar 16 persen pada 2003 telah mengakibatkan PLN kehilangan pendapatan sebesar Rp. 4,8 triliun, sebuah nominal yang tidak kecil. Nilainya setara dengan jumlah subsidi yang diberikan pemerintah kepada PLN.

Dengan demikian, apabila PT. PLN dapat menekan angka losses sampai pada level ideal sebesar 10 persen akan ada peningkatan pendapatan sebesar Rp. 4,8 triliun rupiah. Implikasi dari adanya pendapatan tambahan tersebut : (1) PLN tidak perlu menaikkan harga jual / tarif dasar listrik kepada konsumen, kalaupun terpaksa dinaikkan besarnya tidak seperti kenaikan tarif dasar listrik selama ini; (2) pemerintah tidak perlu memberikan subsidi kepada PLN, sehingga subsidi tersebut bisa dialokasikan ke sektor lain yang lebih dibutuhkan masyarakat, seperti sektor pendidikan dan kesehatan; (3) PLN dapat melakukan investasi baru di sektor ketenagalistrikan, khususnya dipembangkitan, untuk selanjutnya dapat meningkatkan cakupan pelayanan kepada masyarakat.

Berangkat dari berbagai fakta di atas, ke depan setiap kenaikan tarif dasar listrik seharusnya juga diimbangi denga kewajiban PLN untuk menurunkan level angka losses. Sebab kalau tidak, sebesar apapun kenaikan tarif dasar listrik akan " dimakan " oleh tingginya angka losses PLN.

f. Standar keamanan peralatan \& instalasi listrik

Menurut perkiraan Yayasan Lembaga Konsumen Indonesia (YLKI), 85 persen kebakaran yang terjadi di Jakarta terkait dengan ketenagalistrikan. Selain itu juga, masih banyaknya instalasi listrik konsumen yang dipasang oleh tukang batu atau bahkan tukang ojek yang pemasangannya dibawah standar keamanan yang semestinya.

\section{KESIMPULAN}

Sehubungan dengan berlakunya UU No. 31 Tahun 1999 tentang Ketenagalistrikan dan agar terdapat kepastian hukum dalam penyelenggaraan ketenagalistrikan Indonesia, maka pemerintah agar segera menerbitkan peraturan-peraturan pelaksanaan undang-undang tersebut dan mengadakan koordinasi dengan pemerintah daerah dalam kegiatan pemetaan kebutuhan ketenagalistrikan nasional dan porsi pemerintah daerah dalam ketenagalistrikan. Khusus mengenai wilayah usaha PLN agar segera diterbitkan penetapan wilayah usaha PLN yang meliputi wilayah usaha eksisting, sebagai tindak lanjut "pemberian izin usaha penyediaan tenaga listrik" kepada PLN berdasarkan UU No. 31 Tahun 1999. Untuk menarik minat swasta berpartisipasi di bidang ketenagalistrikan, perlu diatur pemberian insentif yang lebih menarik kepada investor bidang kelistrikan khususnya sektor pembangkitan diperlukan pengaturan lebih jelas dan populis. Perlu implementasi prosedur business judment rule untuk setiap aksi korporasi dari mulai tahap inisiasi sampai operasi sebagai preventive action meminimkan krimanalisasi dalam bentuk penerbitan standard operation procedure (SOP) yang merupakan bagian Good Corporate Governance (GCG) PT. PLN (Persero).

\section{Daftar Pustaka}

Titiek Sri Wahyuni. (2012). Pertanggungjawaban Pidana Korporasi (Pt.Pln) Dalam Tindak Pidana Perlindungan Konsumen. Tesis: Program Studi Magister Ilmu Hukum 


\section{[JATISWARA] [Vol. 36 No. 1 Maret 2021]}

Pascasarjana Universitas Hasanuddin Makassar.

Ariono Abdulkadir dkk. (2004), Masalah Ketenagalistrikan di Indonesia (kumpulan artikel), Jakarta: YLKI \& Koalisi Masyarakat Sipil untuk Perbaikan Pelayanan Listrik.

Tim YLKI. (2010). Bersikap Kritis Bertindak Cermat (Panduan Konsumen Menghadapi PenertibanPemakaian Tenaga Listrik), Jakarta: Yayasan Lembaga Konsumen Indonesia.

MR. Roeslan Saleh. (1980), Perbuatan Pidana dan Pertanggungjawaban Pidana. Jakarta: Aksara Baru.

Tri Budiyono. (2011), Hukum Perusahaan. Salatiga: Griya Media.

Muladi dan Dwidja Priyatno. (2010), Pertanggungjawaban Pidana Korporasi. Jakarta: Kencana. 